\title{
Overexpression of activin A in stage IV colorectal cancer
}

\author{
S Wildi, J Kleeff, H Maruyama, C A Maurer, M W Büchler, M Korc
}

\begin{abstract}
Background and aims-Activins and inhibins are dimeric polypeptides that belong to the transforming growth factor beta (TGF- $\beta$ ) superfamily and that bind to transmembrane receptors with serine/ threonine kinase activity. The aim of this study was to characterise, in colon cancer cell lines and in normal and malignant human colon tissues, levels of expression of inhibin subunits that are involved in activin/inhibin dimer formation, and of the type I and II activin receptors (actRI and actRII).
\end{abstract}

Methods-Expression of inhibin subunits and activin receptors was analysed by northern blot analysis. Inhibin $\beta A$ and activin receptor expression were also assessed by use of polymerase chain reaction (PCR). In addition, activin A/inhibin BA localisation in human colon samples was assessed by immunohistochemistry and in situ hybridisation.

Results-Inhibin $\beta A$ mRNA was expressed in $\mathrm{CaCo} 2$ cells but not in SW 837 or SW 1463 cells whereas inhibin $\beta B$ and inhibin $\alpha$ were below the level of detection. In contrast, all four activin receptors were present in the three cell lines. Colon cancers overexpressed inhibin $\beta A$ mRNA in comparison with normal colon, and this overexpression was greatest in stage IV tumours. ActRIb mRNA levels were slightly higher in the normal colon than in cancer tissues. By immunohistochemistry and in situ hybridisation, activin $A$ and inhibin $\beta A$ mRNA were present in the mucosal epithelial cells in normal tissues from patients with stage I disease but were either absent or weakly present in normal tissues from patients with stage IV disease. Conversely, they were present at weak to moderate levels in stage I cancers but at high levels in stage IV cancers.

Conclusions-Our findings indicate that activin $A$ is overexpressed in human colorectal tumours, especially in stage IV disease, raising the possibility that activin A may have a role in advanced colorectal cancer.

(Gut 2001;49:409-417)

Keywords: colorectal cancer; activin $\beta \mathrm{A}$; northern blot analysis

Dr M Korc, Division of

Endocrinology, Diabetes,

and Metabolism, Medical

Sciences I, C240, University

of California, Irvine, CA

92697, USA.

mkorc@uci.edu

Accepted for publication 26 February 2001

Colorectal cancer is the second most common cause of cancer death and the fourth most prevalent carcinoma in the Western world. In the USA there were approximately 131000 new cases of colorectal cancer and 55000 deaths from this disease in $1997 .{ }^{1}$ Patient complacency in reporting symptoms often leads to a delayed diagnosis and contributes to disappointing survival results. Despite the general improvement in surgical therapy, almost 50\% of colorectal cancer patients still die of metastatic tumour, and the five year survival rate for patients with metastasis is only $9 \% .^{23}$ While the best predictor for survival in this disease remains the initial histopathological staging of the tumour, ${ }^{45}$ the basis for this disease aggressiveness may be due in part to alterations in several regulatory pathways that lead to enhanced tumorigenesis. Thus as many as $70 \%$ of these patients harbour mutations in the APC and p53 tumour suppressor genes, approximately $50 \%$ harbour mutations in the K-ras oncogene, whereas approximately $15 \%$ exhibit mutations in the Smad4 gene and in mismatch repair genes. ${ }^{6}$

Loss of tumour suppressor gene function in colon cancer and other malignancies is compounded by ineffective negative growth regulation that is normally exerted by growth suppressing factors. One component of this negative growth regulation is represented by the transforming growth factor beta (TGF- $\beta$ ) superfamily of growth factors and receptors. ${ }^{78}$ It is known that $\mathrm{TGF}-\beta$ s play an important regulatory role in the development of normal colonic epithelium, ${ }^{9}$ and that high serum levels of TGF- $\beta 1$ in patients with colorectal cancer is associated with disease progression. ${ }^{10}{ }^{11}$ However, colon cancer cells are resistant to TGF- $\beta$ mediated growth inhibition as a consequence of the presence of Smad4 mutations, and less commonly Smad2 mutations. ${ }^{3}$ In addition, colon cancers often exhibit microsatellite instability, resulting in mutations in the type II TGF- $\beta$ receptor, which also leads to loss of responsiveness to the growth inhibitory actions of TGF- $\beta$ s. ${ }^{1213}$

The importance of the TGF- $\beta$ pathway in colon carcinogenesis is underscored by two observations. Firstly, there is a marked increase in colon cancer frequency in a family with a germline mutation in the type II TGF- $\beta$ receptor gene. ${ }^{14}$ However, family members do not exhibit an increased incidence of extracolonic malignancies. ${ }^{14}$ Secondly, Smad3 mutant mice uniformly develop metastatic colorectal cancer. ${ }^{15}$ In spite of these observations, little is

Abbreviations used in this paper: TGF- $\beta$, transforming growth factor beta; actRI, activin receptor type I; actRII, activin receptor type II; FBS, fetal bovine serum; DMEM, Dulbecco's modified Eagle's medium; PCR, polymerase chain reaction; BSA, bovine serum albumin; MTT, 3-(4,5-methylthiazol-2-yl)-2,5-diphenyl-tetrazolium bromide; RT, reverse transcription; PBS, phosphate buffered saline. 
known about the potential role in colorectal cancer of other members of the TGF- $\beta$ family that also signal through Smad dependent pathways. Therefore, in the present study we sought to characterise expression of the activin/inhibin members of the TGF- $\beta$ family and the activin/ inhibin receptors in colon cancer cell lines and in sporadic colon cancers in comparison with normal colon tissue.

The activin/inhibin family consists of various dimers of three subunits of inhibin $\beta A$, inhibin $\beta B$, and inhibin $\alpha$. Inhibin $\beta A$ and inhibin $\beta B$ are closely related with $64 \%$ amino acid sequence homology whereas inhibin $\alpha$ shares $27 \%$ and $23 \%$ amino acid homology with inhibin $\beta \mathrm{A}$ and inhibin $\beta \mathrm{B}$, respectively. ${ }^{16-18}$ Inhibin $\beta A$ and $\beta B$ form homo- and heterodimers via disulphide bond linkage yielding the biologically active activin $A(\beta A-\beta A)$, activin $B(\beta B-\beta B)$, and activin $A B(\beta A-\beta B)$. Furthermore, inhibin $\beta$ subunits can form dimers with the inhibin $\alpha$ subunit, generating inhibin $\mathrm{A}(\beta \mathrm{A}-\alpha)$ and inhibin $\mathrm{B}(\beta \mathrm{B}-\alpha)$.

Activins and inhibins contribute to normal growth and development, and participate in the regulation of gonadal and extragonadal functions. ${ }^{16-18}$ They signal through transmembrane serine-threonine kinase receptors which can be divided into two distinct subgroups, type I and type II receptors. ${ }^{18-21}$ Two type I receptors for activin have been described. ${ }^{18-21}$ ActRIb appears to be specific for activin whereas actRI may be shared by other members of the TGF- $\beta$ superfamily. Furthermore, two type II receptors have been identified in humans (actRII and actRIIb) and activin appears to have a higher affinity for actRIIb than for actRII. Activation of appropriate intracellular signalling pathways is dependent on the presence of both type I and II receptors and of Smad2, -3 , and -4 proteins. Thus activation of TGF- $\beta$ and activin receptors leads to phosphorylation of Smad2 and/or Smad3, complex formation of phosphorylated Smad2 or Smad3 with Smad4, and subsequent translocation of these hetero-oligomeric complexes into the nucleus where they modulate gene transcription. ${ }^{78}$

We now report that two of three tested colon cancer cell lines express activin receptors but are generally resistant to the growth inhibitory actions of activin A. We also demonstrate that colon carcinomas overexpress activin A in vivo, and that this overexpression is most pronounced in stage IV disease.

\section{Materials and methods}

MATERIALS

The following materials were purchased: fetal bovine serum (FBS), Dulbecco's modified Eagle's medium (DMEM) and Leibovitz L-15 medium, trypsin solution, and penicillin solution from Irvine Scientific (Santa Ana, California, USA); Genescreen membranes from New England Nuclear (Boston, Massachusetts, USA); restriction enzymes, Genius 3 nonradioactive nucleic acid detection kit, and Genius 4 RNA and random primed labelling kits from Ambion (Austin, Texas, USA); $[\alpha-32$ P] dCTP from Amersham (Arlington Heights,
Illinois, USA); polymerase chain reaction (PCR) primers from Bio Synthesis, Inc. (Lewisville, Texas, USA); RT-Kit and DNA molecular weight markers from Gibco BRL (Gaithersburg, Maryland, USA); and a highly specific affinity purified mouse monoclonal antibody to the human $\beta \mathrm{A}$ subunit of inhibin/ activin from Serotec (Raleigh, North Carolina, USA). All other reagents were from Sigma (St Louis, Missouri, USA). SW 837, SW 1463, and $\mathrm{CaCo} 2$ human colon cancer cell lines were obtained from American Type Culture Collection (Rockville, Maryland, USA). Activin A was a gift from Dr AF Parlow (NIDDK's National Hormone and Pituitary Program).

CELL CULTURE AND PROLIFERATION ASSAY SW 837 and SW 1463 human colon cancer cell lines were routinely grown in Leibovitz L-15 medium, supplemented with 10\% FBS and $100 \mathrm{U} / \mathrm{ml}$ penicillin (complete medium), whereas $\mathrm{CaCo} 2$ was grown in DMEM supplemented with $15 \% \mathrm{FBS}$ and $100 \mathrm{U} / \mathrm{ml}$ penicillin (complete medium). To perform growth assays, cells were plated overnight at a density of 10000 cells/well in 96 well plates and subsequently incubated in serum free medium (Leibovitz/DMEM containing $0.1 \%$ bovine serum albumin (BSA), $5 \mu \mathrm{g} / \mathrm{ml}$ transferrin, $5 \mathrm{ng} / \mathrm{ml}$ sodium selenite, and antibiotics) or complete medium. Incubations were continued for the indicated times in the absence or presence of activin $A$, prior to the addition of 3-(4,5-methylthiazol-2-yl)-2,5-diphenyltetrazolium bromide (MTT, $62.5 \mu \mathrm{g} / \mathrm{well}$ ) for four hours. ${ }^{22}$ Cellular MTT was solubilised with acidic isopropanol. Optical density was measured at $570 \mathrm{~nm}$ with an ELISA plate reader (Molecular Devices, Menlo Park, California, USA), as previously reported. ${ }^{23}$

\section{TISSUE SAMPLES}

Normal colon tissue samples as well as cancer samples $(n=41)$ were obtained from patients with colorectal cancer undergoing surgery for their disease (see table 1). Normal tissue was taken from the same patients at a distance of at least of $10 \mathrm{~cm}$ from the tumour site. According to the TNM classification of the Union Internationale Contre le Cancer, there were 13 stage I cancers, seven stage II cancers, seven stage III cancers, and 14 stage IV cancers. Freshly removed tissue samples were fixed in Bouin or $10 \%$ formaldehyde solution and paraffin embedded for histological analysis. Tissue samples were also frozen in liquid nitrogen immediately on surgical removal and stored at $-80^{\circ} \mathrm{C}$ until use for RNA extraction. All studies were approved by the ethics committee of the University of Bern and by the human subjects committee of the University of California, Irvine.

\section{CONSTRUCTION OF VECTORS}

cDNAs encoding sequences corresponding to activin receptor I (actRI) and the inhibin $\alpha$ subunit were produced by PCR amplification of single stranded cDNA that was reversed transcribed from human placenta RNA. The PCR products were generated using standard 
Table 1 Summary of clinical characteristics of 41 patients undergoing surgery for colorectal cancer

\begin{tabular}{llllll}
\hline & Stage ${ }^{*}(n=13)$ & Stage $I I(n=7)$ & Stage III $(n=7)$ & Stage $I V(n=14)$ & Overall $(n=41)$ \\
\hline Sex $(\mathrm{M}: \mathrm{F})$ & $5: 8$ & $5: 2$ & $4: 3$ & $9: 5$ & $23: 18$ \\
Age (mean (range) & $72.4(54-87)$ & $66.6(54-76)$ & $64(49-82)$ & $70.1(54-87)$ & $68.3(49-87)$ \\
Localisation of tumour & Colon: 2 & Colon: 5 & Colon: 3 & Colon: 6 & Colon: 16 \\
& Rectum: 10 & Rectum: 2 & Rectum: 2 & Rectum: 6 & Rectum: 20 \\
& Caecum: 1 & & Sigmoid: 2 & Sigmoid: 2 & Sigmoid: 4 \\
& G1: 1 & G2: 5 & G2: 6 & G2: 10 & Caecum: 1 \\
& G2: 11 & G3: 1 & G3: 1 & G3:3 & G2: 32 \\
& Unknown: 1 & Unknown: 1 & & Unknown: 1 & G3: 5 \\
& & & & & Unknown: 3 \\
\hline
\end{tabular}

^According to the TNM classification of the Union Internationale Contre le Cancer.

conditions, subcloned into pGEM3Zf (actRI) and Bluescript-IISK+ (inhibin $\alpha$ ) vectors, and authenticity was confirmed by sequencing. The actRI cDNA consisted of a $401 \mathrm{bp}$ fragment (nucleotides 172-572) and the inhibin $\alpha$ cDNA consisted of a $405 \mathrm{bp}$ fragment (nucleotides 478-882), based on the published human sequences. ${ }^{19-21}$ The primers consisted of a three nucleotide stretch followed by a restriction site (underlined) and the respective cDNA sequence. The actRI primer pair was sense 5'- GACGGATCCTAAGCGTCACACTGCC AAG, and antisense 5'-CAGAAGCTTTT CCCTGCTCATAAACCTGG. The inhibin $\alpha$ primer pair was sense 5'-GACGGATCCA GATACATGTTCCGGCCATC, and antisense 5'-CAGGAATTCCAGAGCAGAGG GA-GACCAAG. A $1.7 \mathrm{~kb}$ Clal-Xbal fragment of human actRIb cDNA, a $2.6 \mathrm{~kb}$ Xbal-BamHI fragment of mouse actRII cDNA (93\% homology to human), and a $1.7 \mathrm{~kb}$ EcoRI-BamHI fragment of mouse actRIIb cDNA (91\% homology to human) were gifts from Dr J Massagué (Memorial Sloan-Kettering Cancer Center New York, New York, USA). A 380 bp activin $\beta$ A (91\% homology to human) (nucleotides 10251404; Genbank accession X69619) and $270 \mathrm{bp}$ activin $\beta \mathrm{B}$ ( $89 \%$ homology to human) (nucleotides 180-449; Genbank accession X69620) fragments of mouse origin were gifts from Dr M O'Connor (University of Wisconsin, Wisconsin, USA). Authenticity was confirmed by sequencing.

RNA EXTRACTION AND NORTHERN BLOT ANALYSIS Total RNA was extracted by a guanidinium thiocyanate phenol chloroform method. ${ }^{24}$ Where indicated, polyA ${ }^{+}-\mathrm{RNA}$ was prepared by affinity chromatography on oligo-dT cellulose. RNA was size fractionated on $1.2 \%$ agarose/ 1.8 $\mathrm{M}$ formaldehyde gels, electrotransferred onto nylon membranes, and cross linked by UV irradiation. Blots were prehybridised and hybridised with cDNA probes and washed under high stringency conditions as previously reported..$^{25}$ Blots were then exposed at $-80^{\circ} \mathrm{C}$ to Kodak BiomaxMS films and the resulting autoradiographs were scanned to quantify the intensity of the radiographic bands. A BamHI $190 \mathrm{~kb}$ fragment of mouse 7S cDNA that hybridises with human cytoplasmic RNA was used to confirm equal RNA loading and transfer. ${ }^{26}$

PCR ANALYSIS

PCR amplified products were fractionated on a $1 \%$ agarose gel containing ethidium bromide
$(0.1 \mu \mathrm{g} / \mathrm{ml})$ and visualised by UV transillumination. The gels were incubated in $0.25 \mathrm{M} \mathrm{HCl}$ for 30 minutes at $23^{\circ} \mathrm{C}$. DNA was transferred by capillary action in $0.4 \mathrm{M} \mathrm{NaOH}$ to Nylon membranes (Hybond $\mathrm{N}+$ ). Hybridisation was performed with $\left[\alpha-{ }^{32} \mathrm{P}\right]$-dCTP labelled cDNA in $10 \mathrm{ml}$ hybridisation solution $(0.75 \mathrm{M} \mathrm{NaCl}$, $5 \mathrm{mM}$ EDTA, $\mathrm{pH}$ 8.0, $50 \mathrm{mM}$ sodium phosphate, $\mathrm{pH} 7.4,25 \%$ formamide, $5 \times$ Denhart's solution, $10 \%$ dextran sulphate, $1 \%$ SDS, and $1 \%$ salmon sperm DNA). The membranes were washed twice at $23^{\circ} \mathrm{C}$ in $2 \times$ SSC and twice at $42^{\circ} \mathrm{C}$ in $0.1 \times$ SSPE, $2 \%$ SDS, and subsequently exposed at $-80^{\circ} \mathrm{C}$ to Kodak BiomaxMS films for the appropriate time. Primers for the PCR analysis consisted of a three nucleotide stretch followed by a restriction site (italised) and the respective cDNA sequence. The primer pairs were: sense, 5' - AGTGGATCCAAAAGATGGCCACAAA CCTG and antisense, 5'-GTAGAATTCTTT CCTCCTCAAATGGCAAC (actRII); sense, 5'-AGTGGATCCACATGGTGGAGAAGAG GGTG and antisense, 5'-GTAGAATTCGGG TGCTATGATCCA-GTCGT (activin $\beta \mathrm{B}$ ); sense, 5'-AGTGGATCCGCACTTGAAGAA GAGACCCG and antisense, 5'-GTAGAATT CCTGCTGGAGACAGGGAAGAC (activin $\beta A)$.

To perform quantitative reverse transcription (RT)-PCR, total RNA (2 $\mu \mathrm{g} / \mathrm{sample})$ pooled from each tumour stage and the corresponding normal tissue samples $(n=41)$ were reverse transcribed using the SuperScript Preamplification System for First Strand cDNA Synthesis, and subjected to two rounds of PCR amplification. ${ }^{27}$ In the first PCR reaction, two composite primers were used. Each composite primer had the target gene primer sequence attached to a short stretch of sequence designed to hybridise to opposite strands of a heterologous DNA fragment, thus generating a PCR product of a different size than the target DNA. This PCR product that has the same primer templates as the target DNA was used as the internal standard. Concentrations of the PCR were measured and diluted to 100 attomole/ $\mu$ l. In the second step, dilution of the control PCR product was then amplified together with the target cDNA using the gene specific primers. Competitive PCR was carried out under standard conditions for 27 cycles. RT-PCR products were size fractionated on a $2 \%$ agarose gel and stained with ethidium bromide. The bands were scanned 
A

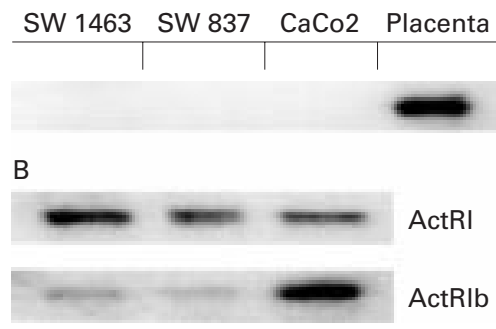

Figure 1 Northern blot analysis of Poly $A^{+}-R N A$.

Poly $A^{+}-R N A$ ( $\left.2 \mu \mathrm{g} / \mathrm{lane}\right)$ was prepared from the cell lines $S W 1463, S W$ 837, and CaCo2, and hybridised with ${ }^{32} \mathrm{P}$ labelled cDNA probes $(500000 \mathrm{cpm} / \mathrm{ml})$ specific for inhibin $\beta A(A)$, or with ${ }^{32} P$ labelled $c D N A$ probes $(500000 \mathrm{cpm} / \mathrm{ml})$ specific for actRI and actRIb (B). Human placenta RNA served as a positive control for the inhibin $\beta A$ transcript. Exposure times were 12 hours.

and quantitated by a gel video system (EagleEye II; Stratagene). The relative concentration of the target cDNA was calculated by comparison with the standard values. We used the following primer pair: sense 5'-GCACTTG AAGAAGAGACCCG and antisense 5'-CTG CTGGAGACAGGGAAGAC.

IMMUNOBLOTTING

After washing with phosphate buffered saline (PBS, $4^{\circ} \mathrm{C}$ ), cells were solubilised in lysis buffer containing $50 \mathrm{mM}$ Tris, $150 \mathrm{mM} \mathrm{NaCl}, 2 \mathrm{mM}$ EDTA, 1\% Nonidet P-40, 0.1\% SDS, $1 \%$ sodium deoxycholate, $1 \mathrm{mM}$ sodium vanadate, $50 \mathrm{mM}$ sodium fluoride, $100 \mu \mathrm{g} / \mathrm{ml}$ benzamidine, $10 \mu \mathrm{g} / \mathrm{ml}$ leupeptin, and $1 \mathrm{mM}$ phenylmethylsulphonyl fluoride. Proteins were subjected to SDS-polyacrylamide gel electrophoresis and transferred to Immobilon $\mathrm{P}$ membranes. Membranes were incubated for

A

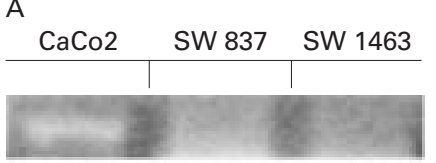

Inhibin $\beta A$

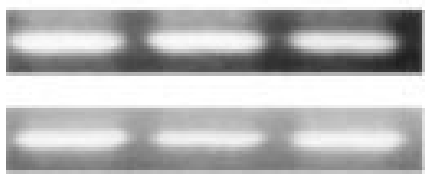

ActRII

ActRIlb

B

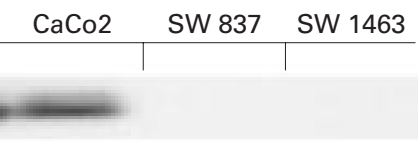

Inhibin $\beta A$

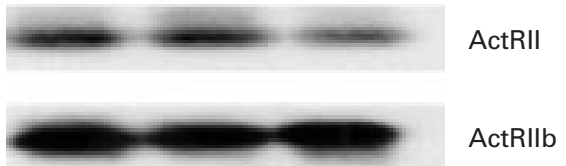

Figure 2 Polymerase chain reaction (PCR) analysis. $R N A$ from the cell lines ( $S W 1463, S W 837$, and $\mathrm{CaCo}$ ) was reverse transcribed and subjected to PCR using primers for inhibin $\beta A$, actRII, and actRIIb, as described in the materials and methods section. (A) Ethidium bromide staining. (B) Southern blot analysis. Filters were hybridised with $a_{-}^{-32}$ P labelled cDNA fragments $(500000 \mathrm{cpm} / \mathrm{ml})$ which covered the corresponding amplified regions. Exposure time was five hours.
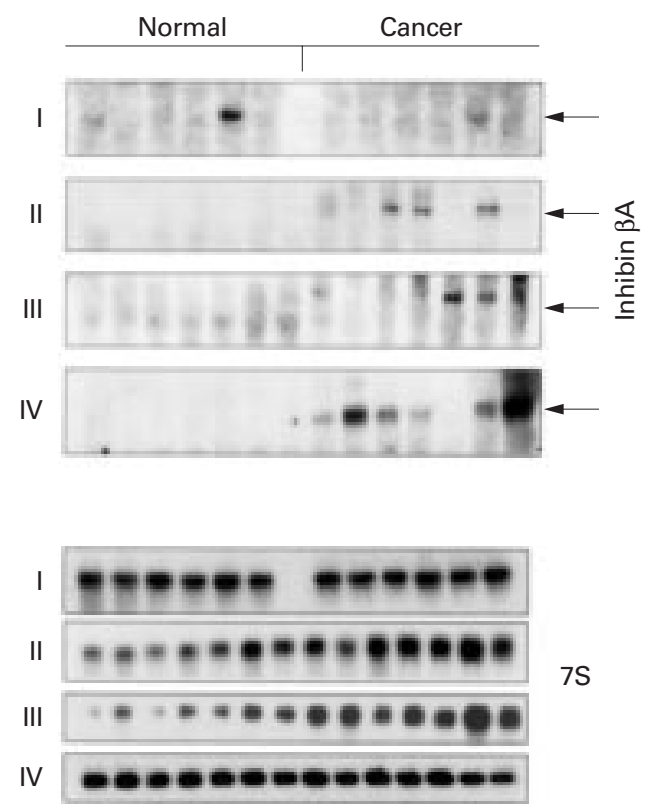

Figure 3 Expression of inhibin $\beta A$ in human colon. Total RNA (20 $\mu \mathrm{g} /$ lane) from 28 (seven/stage) colon cancers and the corresponding normal colon mucosa samples were subjected to northern blot analysis. (A) $A{ }^{32} P$ labelled inhibin $\beta A \mathrm{cDNA}$ probe $(500000 \mathrm{cpm} / \mathrm{ml})$ was used to perform hybridisations. Exposure time was 12 hours. (B) $A$ ${ }^{32} \mathrm{P}$ labelled $7 \mathrm{~S} \mathrm{cDNA}$ probe $(50000 \mathrm{cpm} / \mathrm{ml})$ was used to confirm equivalent loading of lanes. Exposure time was six hours. Roman numerals on the left indicate disease stage.

90 minutes with a highly specific affinity purified mouse monoclonal antibody to the human $\beta A$ subunit of inhibin/activin, corresponding to the 82-114 residues of the peptide. Membranes were then washed and incubated with a secondary antibody against mouse for $60 \mathrm{~min}$ utes. Following additional washing, visualisation was performed by enhanced chemiluminescence.

IMMUNOHISTOCHEMISTRY

The same highly specific monoclonal antibody to the human $\beta$ A subunit of inhibin/activin that was used for immunoblotting was also utilised for immunohistochemistry. Paraffin embedded sections $(4 \mu \mathrm{m})$ from colon cancer and the corresponding normal colon tissues were subjected to immunostaining using the streptavidin-peroxidase technique..$^{25}{ }^{26}$ Endogenous peroxidase activity was blocked by incubation for 30 minutes with $0.3 \%$ hydrogen peroxide in methanol. Tissue sections were incubated for 15 minutes $\left(23^{\circ} \mathrm{C}\right)$ with $10 \%$ normal goat serum and incubated for 16 hours at $4^{\circ} \mathrm{C}$ with activin antibody $(10 \mathrm{ng} / \mathrm{ml})$ in PBS containing $1 \%$ BSA. Bound antibodies were detected with biotinylated goat antimouse IgG secondary antibodies and streptavidinperoxidase complex, using diaminobenzidine tetrahydrochloride as the substrate. Sections were counterstained with Mayer's haematoxylin. Sections incubated without primary antibody did not yield positive immunoreactivity.

IN SITU HYBRIDISATION

To perform in situ hybridisation, tissue sections (4 $\mu \mathrm{m}$ thick) were placed on 3-aminopropylmethoxysilane coated slides, deparaffinised, 

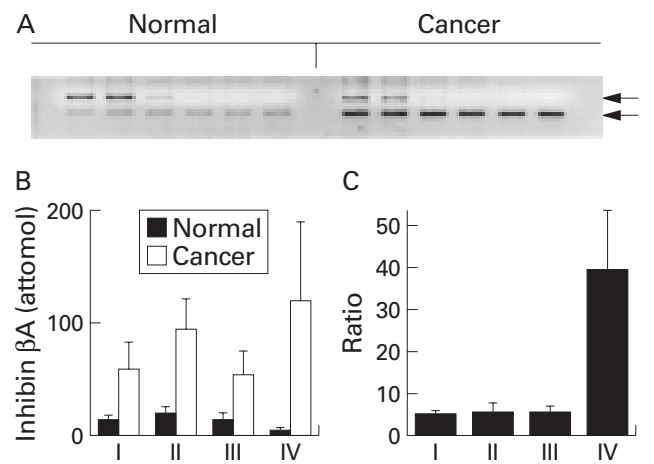

C

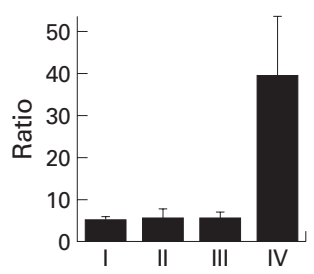

Figure 4 Quantitative reverse transcription-polymerase chain reaction (RT-PCR) of inhibin $\beta A m R N A$. First strand $c D N A$ synthesis was performed using pooled total $m R N A$ from each stage $(I-I V)$ and analysed by quantitative RT-PCR as described in the materials and methods section. (A) Representative ethidium bromide gel (stage III). The upper arrow indicates dilution series whereas the lower arrow denotes amplified inhibin $\beta A$ $m R N A$ from pooled stage III RNA samples. (B) Concentrations of inhibin $\beta A m R N A$ in normal and cancerous colon tissues. (C) Ratio cancer/normal in activin $\beta A$ mRNA expression. Vertical bars denote SEM values.

and incubated at $23^{\circ} \mathrm{C}$ for 20 minutes with $0.2 \mathrm{~N} \mathrm{HCl}$ and at $37^{\circ} \mathrm{C}$ for 15 minutes with $10 \mu \mathrm{g} / \mathrm{ml}$ of proteinase $\mathrm{K}$. The sections were then postfixed for five minutes in PBS containing $4 \%$ paraformaldehyde, and incubated twice with PBS containing $2 \mathrm{mg} / \mathrm{ml}$ glycine and once in $50 \%(\mathrm{~V} / \mathrm{V})$ formamide $/ 2 \times \mathrm{SSC}$ for one hour. Hybridisation was performed in a moist chamber for 16 hours at $50^{\circ} \mathrm{C}$, following addition of $100 \mu \mathrm{l}$ of hybridisation buffer that contained $0.6 \mathrm{M} \mathrm{NaCl}, 1 \mathrm{mM}$ EDTA, $10 \mathrm{mM}$ Tris $\mathrm{HCl}$ (pH 7.6), $0.25 \%$ SDS, $200 \mu \mathrm{g} / \mathrm{ml}$ yeast tRNA, $1 \times$ Denhart's solution, $10 \%$ dextran sulphate, $40 \%$ formamide, and the digoxigenin labelled riboprobe $(100 \mathrm{ng} / \mathrm{ml})$, as previously reported. ${ }^{28-31}$ The probes were labelled with digoxigenin-UTP by T3 or T7 RNA polymerase using the Genius 4 RNA labelling kit. Sections were then washed at $42^{\circ} \mathrm{C}$ with $50 \%$ formamide $/ 2 \times$ SSC for 20 minutes, $2 \times$ SCC for 20 minutes, and $0.2 \times$ SSC for 20 minutes. The Genius 3 non-radioactive nucleic acid detection kit was used for immunological detection. ${ }^{28-31}$ Sections were washed with buffer 1 solution (100 mM Tris $\mathrm{HCl}$ and $150 \mathrm{mM}$ $\mathrm{NaCl}, \mathrm{pH} 7.5)$ and incubated with $1 \%$ (W/V) blocking reagent in buffer 1 solution for 60 minutes at $23^{\circ} \mathrm{C}$. After incubation for $30 \mathrm{~min}-$ utes at $23^{\circ} \mathrm{C}$ with a $1: 2000$ dilution of an alkaline phosphatase conjugated polyclonal sheep antidigoxigenin Fab fragment antibody, sections were washed twice for 15 minutes at $23^{\circ} \mathrm{C}$ with buffer 1 solution containing $0.2 \%$ Tween 20 , and equilibrated for two minutes with 100 $\mathrm{mM}$ Tris $\mathrm{HCl}, 100 \mathrm{mM} \mathrm{NaCl}$, and $50 \mathrm{mM}$ $\mathrm{MgCl}_{2}$ at $\mathrm{pH}$ 9.5. Sections were then incubated with colour solution containing nitroblue tetrazolium and X-phosphate in a dark box for 2-3 hours. After the reaction was stopped with TE buffer ( $10 \mathrm{mM}$ Tris $\mathrm{HCl}, 1 \mathrm{mM}$ EDTA, $\mathrm{pH}$ 8.0 ), the sections were mounted in aqueous mounting medium.

\section{Results}

EFFECTS OF ACTIVIN A ON COLON CANCER CELL GROWTH

After a 48 hour incubation in serum free medium, activin A inhibited the growth of SW 1463 colon cancer cells in a dose dependent manner. In three experiments, maximal inhibitory effects of 19 (1)\% (mean (SEM)) $(\mathrm{p}<0.05)$ occurred at a concentration of 100 $\mathrm{ng} / \mathrm{ml}$ of activin A. A comparable growth inhibitory effect $(\mathrm{p}<0.05)$ also occurred in medium supplemented with $10 \%$ FBS. However, activin $\mathrm{A}$ had no effect in $\mathrm{CaCo} 2$ or SW 837 cells, irrespective of the absence or presence of serum. Furthermore, all three cell lines were resistant to the growth inhibitory effects of TGF- $\beta 1$.

EXPRESSION OF THE ACTIVIN-INHIBIN SUBUNITS AND ACTIVIN RECEPTORS IN HUMAN COLON CANCER CELL LINES

Northern blot analysis of polyA ${ }^{+}-\mathrm{RNA}$ isolated from SW 837, SW 1463, and $\mathrm{CaCo} 2$ colon cancer cell lines failed to reveal the presence of activin/inhibin $\beta \mathrm{A}, \beta \mathrm{B}$, or $\alpha$ mRNA transcripts. In contrast, the inhibin $\beta A$ transcript was readily evident in placenta RNA which was used as a positive control (fig 1A). Furthermore, activin $\beta \mathrm{A}$ was not detectable in all three cell lines using western blotting. As a positive control we used activin $\beta$ A that was readily detected by the antibody exhibiting a single band of the expected size (not shown). Northern blot analysis of polyA ${ }^{+}-\mathrm{RNA}$ revealed that the $4.0 \mathrm{~kb}$ actRI mRNA moiety was present at relatively equal levels in all three cell lines (fig 1B). Furthermore, all three cell lines also expressed the $5.2 \mathrm{~kb}$ actRIb mRNA transcript (fig $1 \mathrm{~B}) . \mathrm{CaCo} 2$ cells expressed the highest levels of actRIb whereas SW 837 and SW 1463 cells expressed relatively low levels of this

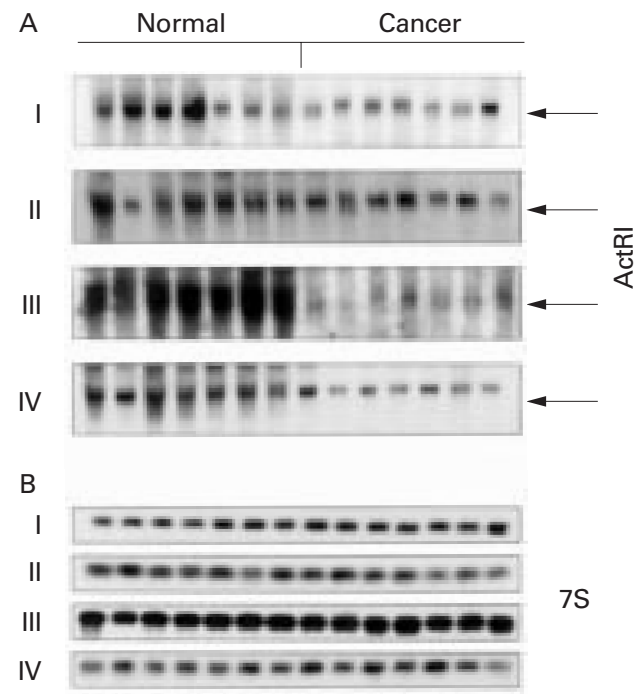

Figure 5 Expression of actRI in human colon. Total RNA (20 $\mu \mathrm{g} /$ lane) from 28 (seven/stage) colon cancers and the corresponding normal colon mucosa samples were subjected to northern blot analysis. (A) $A{ }^{32} P$ labelled actRI cDNA probe $(500000 \mathrm{cpm} / \mathrm{ml})$ was used to perform hybridisations. Exposure time was 12 hours. (B) $A^{32} P$ labeled $7 S \mathrm{cDNA}$ probe $(50000 \mathrm{cpm} / \mathrm{ml})$ was used to confirm equivalent loading of lanes. Exposure time was six hours. Roman numerals on the left indicate disease stage. 
mRNA moiety (fig 1B). ActRII and actRIIb mRNA transcripts were below the level of detection by northern blotting of polyA ${ }^{+}-\mathrm{RNA}$ (not shown).

To further assess expression of activin $\beta \mathrm{A}$ and type II activin receptors in colon cancer cell lines, a highly sensitive RT-PCR analysis was performed. This analysis revealed the presence of an inhibin $\beta A$ mRNA transcript in $\mathrm{CaCo} 2$ cells but not in SW 837 or SW 1463 cells (fig 2A). In contrast, actRII and actRIIb transcripts were detected by RT-PCR in all three cell lines. Authenticity of the PCR products was confirmed by Southern blotting using

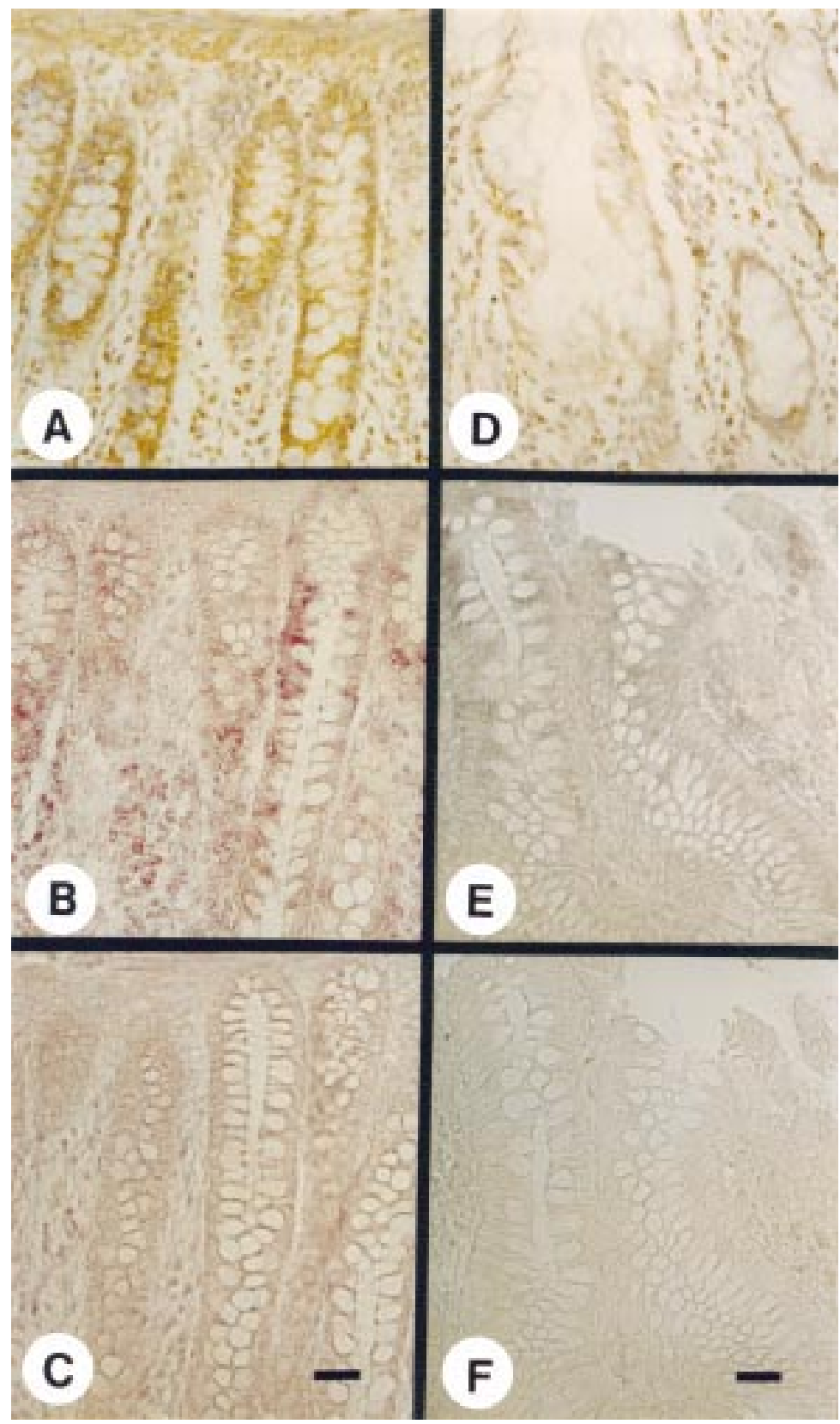

Figure 6 Immunohistochemical and in situ hybridisation analysis in the normal colon. Moderate inhibin/activin $\beta A$ immunoreactivity was readily evident in the normal mucosa from patients with stage I disease $(A)$. This sample also expressed relatively high levels of inhibin $\beta A m R N A$ by northern blot analysis. In contrast, inhibin/activin $\beta A$ immunoreactivity was relatively weak in normal mucosa from patients with stage IV disease (D). In situ hybridisation revealed a moderate inhibin $\beta A m R N A$ signal (B) in stage I disease and a very weak inhibin $\beta A m R N A$ signal in stage IV disease $(E)$. The sense probe $(C, F)$ did not yield any specific signal. Scale bars, $25 \mu \mathrm{m}$. $\alpha-{ }^{32} \mathrm{P}$ labelled actRII, actRIIb, and activin $\beta A$ cDNA fragments which covered the amplified regions (fig $2 \mathrm{~B}$ ).

NORTHERN BLOT ANALYSIS IN HUMAN COLON TISSUES

Next, we examined tissue samples of 41 patients undergoing surgery for colorectal cancer. The clinical characteristics of the patients are summarised in table 1 . None of the patients received preoperative chemotherapy or radiation therapy. Northern blot analysis of total RNA isolated from the normal portion of the colon of these patients revealed that the $6.5 \mathrm{~kb}$ inhibin $\beta \mathrm{A}$ mRNA moiety was visible in only two samples. In contrast, inhibin $\beta A$ was strongly expressed in 26 of 41 cancer tissues. Moreover, the frequency of overexpression of inhibin $\beta \mathrm{A}$ mRNA tended to correlate with disease stage. Thus, six of 13 stage I samples (46\%) and 13 of 14 stage IV samples (93\%) expressed high levels of the inhibin $\beta A$ mRNA. A representative set of northern blots is shown in fig 3 .

To quantify the differences in inhibin $\beta A$ expression in normal and cancer samples, quantitative RT-PCR was carried out. For all four stages of disease, inhibin $\beta A$ mRNA levels were elevated in the cancer samples compared with levels in the respective control tissues (fig 4). When the data were expressed as a ratio of optical density for cancer versus normal samples, stages I-III exhibited five to sixfold increases in levels of inhibin $\beta$ A compared with the respective normal tissues (fig 4). There was a dramatic 40-fold increase in this ratio in stage IV disease (fig 4 ). In contrast, inhibin $\beta B$ and $\alpha$ mRNA transcripts were below the level of detection by northern blotting in all 41 normal and cancer samples.

We next determined expression levels of the different activin receptors in the same tissue. The $4.0 \mathrm{~kb}$ actRI mRNA transcript was present in all 41 cancer and normal tissue samples (fig 5). Densitometric analysis indicated that by comparison with the normal colon there was a 1.7-fold decrease in actRI mRNA levels in stage I and II disease, a 3.1-fold decrease in stage III disease, and a 1.8-fold decrease in stage IV disease. The actRIb and actRIIb mRNA transcripts were below the levels of detection by northern blotting of total RNA in both the normal and cancer tissues (data not shown). In contrast, the 3.0 and $6.0 \mathrm{~kb}$ act RII mRNA transcripts were visible in eight of 13 normal and in eight of 13 cancer samples in stage I disease, and in 10 of 14 normal, and in 11 of 14 cancer samples in stage IV disease, respectively. Overall, actRII mRNA levels were similar in normal and cancer samples in all four stages.

\section{IMMUNOHISTOCHEMISTRY AND IN SITU} HYBRIDISATION

The site of expression in the colon samples of inhibin/activin $\beta A$ was assessed by immunohistochemistry and in situ hybridisation. Moderately strong inhibin/activin $\beta \mathrm{A}$ immunoreactivity was present in the mucosa from the normal colon of patients with stage I disease where it was most evident in the epithelial cells lining the crypts. A sample with relatively strong 


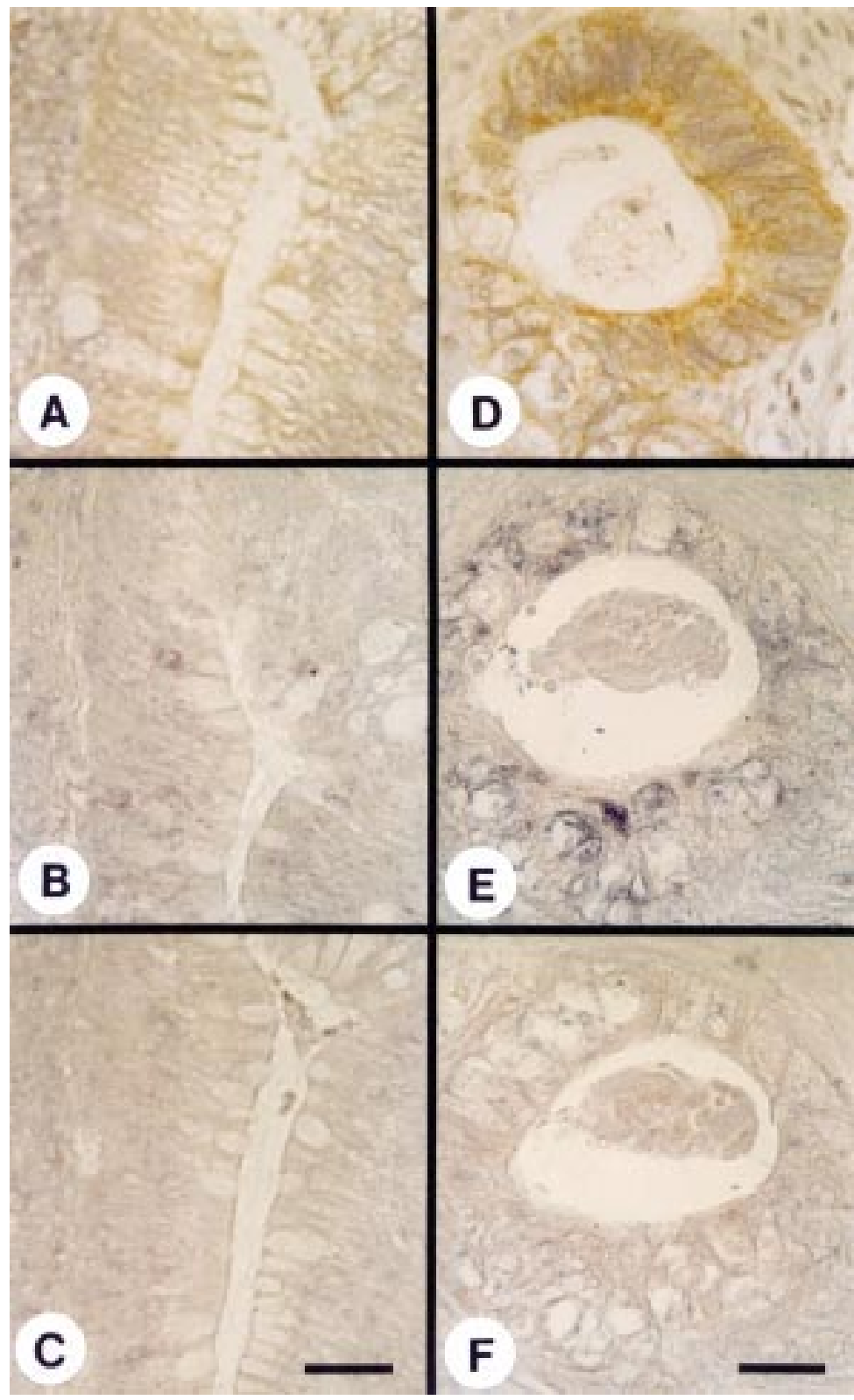

Figure 7 Immunohistochemical and in situ hybridisation analysis in colon cancer. Only faint immunoreactivity for inhibin/activin $\beta A$ was visible in stage I disease $(A)$ whereas stage IV disease exhibited strong inhibin/activin $\beta A$ immunoreactivity (D). In situ hybridisation revealed a weak inhibin $\beta A m R N A$ signal in stage I disease (B) and a strong signal in stage $I V$ disease $(E)$. The sense probe $(C, F)$ did not yield any specific signal. Scale bars, $25 \mu \mathrm{m}$. from patients with stage IV disease (fig 6D). Conversely, faint inhibin/activin $\beta \mathrm{A}$ immunoreactivity was only occasionally evident in the cancer cells from stage I disease (fig 7A) whereas strong inhibin/activin $\beta \mathrm{A}$ immunoreactivity was present in the cancer cells from stage IV disease (fig $7 \mathrm{D}$, table 2).

In situ hybridisation was performed in 21 colon tissues to determine the exact site of expression of inhibin $\beta A$ mRNA. In normal tissues, the in situ hybridisation signal corresponding to inhibin $\beta A$ mRNA was relatively strong in three of three stage I samples (fig 6B) and either absent $(n=3)$ or very weak $(n=2)$ in stage IV samples (fig 6E). In contrast, inhibin $\beta A$ mRNA was expressed at low levels in two of seven samples from patients with stage I disease, and at high levels in three of four samples from patients with stage IV disease. In situ hybridisation with sense probes did not produce any specific signal in either the normal (fig 6C, F) or cancer samples (fig 7C, F). The results for the cancer samples are summarised in table 3.

\section{Discussion}

Activins were initially characterised as stimulators of follicle stimulating hormone production from the anterior pituitary. ${ }^{32}{ }^{33}$ Subsequently, they were detected in reproductive and other tissues where they were found to exert important endocrine, paracrine, and autocrine actions that contribute to the regulation of cell proliferation, development, and differentiated functions. ${ }^{16}{ }^{17}$ The multifunctional nature of activins is underscored by the finding that activin A inhibits growth in a number of cell lines, including prostate cancer cell line, vascular endothelial cells, mammary epithelial cells, and hepatocytes ${ }^{34-38}$ but stimulates the growth of BALB/c 3T3 fibroblasts, granulosa cells, erythropoietic progenitor cells, and ovarian cancer cell lines. ${ }^{39-42}$ Interestingly, inhibin $\alpha$ deficient mice exhibit high levels of circulating activin and develop gonadal stromal tumours, ${ }^{43}{ }^{44}$ raising the possibility that increased activin expression may be tumorigenic under certain circumstances. This concept is supported by the findings that pancreatic, prostate, and ovarian cancers overexpress activin A, ${ }^{28} 4546$ and that patients with endometrial and cervical cancers have high serum levels of activin $\mathrm{A} .{ }^{47}$

In the present study we determined that $\mathrm{CaCo} 2$ colorectal cancer cells expressed inhibin $\beta A$ mRNA whereas SW 837 and SW 1463 did not. All four activin receptors were present in these three cell lines. However, only immunoreactivity that also expressed relatively high levels of inhibin $\beta \mathrm{A}$ by northern blot analysis is shown in fig 6A. In contrast, only faint inhibin/activin $\beta \mathrm{A}$ immunoreactivity was evident in this cell type in the normal mucosa

Table 2 Summary of expression of activin/inhibin ligands and receptors by northern blotting of normal and cancer tissues from 41 patients undergoing surgery for colorectal cancer disease

\begin{tabular}{|c|c|c|c|c|c|c|c|c|}
\hline & \multicolumn{2}{|l|}{ Stage I } & \multicolumn{2}{|l|}{ Stage II } & \multicolumn{2}{|l|}{ Stage III } & \multicolumn{2}{|l|}{ Stage IV } \\
\hline & Normal & Cancer & Normal & Cancer & Normal & Cancer & Normal & Cancer \\
\hline Inhibin $\beta \mathrm{A}$ & $2 / 13$ & $6 / 13$ & $0 / 7$ & $3 / 7$ & $0 / 7$ & $4 / 7$ & $0 / 14$ & $13 / 14$ \\
\hline Inhibin $\beta B$ & - & - & - & - & - & - & - & - \\
\hline Inhibin $\alpha$ & - & - & - & - & - & - & - & - \\
\hline ActRI & $13 / 13$ & $13 / 13$ & $7 / 7$ & $7 / 7$ & $7 / 7$ & $7 / 7$ & $14 / 14$ & $14 / 14$ \\
\hline ActRIb & - & - & - & - & - & - & - & - \\
\hline ActRII & $8 / 13$ & $8 / 13$ & $0 / 7$ & $4 / 7$ & $3 / 7$ & $1 / 7$ & $10 / 14$ & $11 / 14$ \\
\hline ActRIIb & - & - & - & - & - & - & - & - \\
\hline
\end{tabular}

-, below the level of detection. 
Table 3 Expression of inhibin $\beta A$ in colon cancer tissues, analysed by different methods

\begin{tabular}{llll}
\hline & Northern blot analysis $^{1}$ & Immunohistochemistry $^{2}$ & In situ hybridisation $^{3}$ \\
\hline Stage I & 6 of 13 samples $(46 \%)$ & 1 of 5 samples $(20 \%)$ & 2 of 7 samples $(29 \%)$ \\
Stage IV & 13 of 14 samples $(93 \%)$ & 4 of 5 samples $(80 \%)$ & 5 of 6 samples $(83 \%)$
\end{tabular}

${ }^{1}$ Positive inhibin $\beta$ A mRNA expression.

${ }^{2}$ Positive inhibin/activin $\beta \mathrm{A}$ immunoreactivity within the cancer cells.

${ }^{3}$ Positive inhibin $\beta \mathrm{A}$ in situ hybridisation signals within the cancer cells.

$\mathrm{CaCo} 2$ cells readily exhibited both actRI and actRIIb mRNA transcripts by northern blotting whereas ActRII and actRIIb were only readily detectable by PCR analysis. It is not surprising therefore that exogenous activin A did not alter the growth of either SW 837 or $\mathrm{CaCo} 2$ cells. None the less, activin A exerted a slight but significant growth inhibitory effect in SW 1463 cells, and this inhibitory effect was not altered in the presence of serum. These results differ from our findings in pancreatic cancer cell lines, some of which are growth stimulated in the presence of serum and growth inhibited in its absence. ${ }^{28}$ These observations suggest that colon cancer cells are generally resistant to the actions of activin $\mathrm{A}$, or are slightly growth inhibited by this member of the TGF- $\beta$ family. This resistance could be due to perturbations in the Smad signalling cascade or to the fact that our cell lines expressed low levels of actRII and actRIIb that could only be detected by PCR. Indeed, low levels of activin receptors have been implicated in the resistance of breast cancer cells to activin. ${ }^{48}$

Analysis of human colon cancer samples revealed that inhibin $\beta \mathrm{A}$, which forms homodimers to yield activin $A$, is overexpressed in colon cancer, most notably in stage IV disease. In stage I colorectal disease, only $46 \%$ of all patients expressed the inhibin $\beta A$ subunit whereas almost all patients with stage IV disease (93\%) showed enhanced expression of this subunit in the cancer cells. Furthermore, in normal tissue samples from the same patients we detected inhibin $\beta$ A only in stage I cases whereas in stages II-IV this transcript was below the level of detection by northern blot analysis.

To further characterise this difference in expression, we performed quantitative RT-PCR of pooled total RNA for every stage. There was a stage related increase in the cancer to normal ratio of inhibin $\beta A$ mRNA levels. Thus in stage IV disease there was a decrease in inhibin $\beta A$ $m R N A$ levels in normal samples and an increase in cancer samples. Consequently, there was a 40 -fold increase in the ratio of cancer to normal inhibin $\beta \mathrm{A}$ transcript. These observations were consistent with the immunohistochemical data which revealed faint activin $\beta \mathrm{A}$ immunoreactivity in one of five cancer samples from stage I disease, and strong activin $\beta \mathrm{A}$ immunoreactivity in four of five cancer samples from stage IV disease. This was a complete reversal of the findings in the normal tissues inasmuch as activin $\beta \mathrm{A}$ immunoreactivity was of moderate intensity in the normal mucosa from stage I disease but either absent or only weakly present in the normal mucosa from stage IV disease. The in situ hybridisation data confirmed that inhibin $\beta A$ mRNA was expressed at higher levels in the normal mucosa of stage I disease by comparison with stage IV disease. It also demonstrated that the strongest and most abundant inhibin $\beta \mathrm{A}$ mRNA signal was seen in the cancer cells of patients with stage IV disease. Taken together, these observations indicate that colon cancer cells acquire an increased capacity to express inhibin $\beta A$ with disease progression while the normal colonic mucosa progressively loses this capacity.

ActRI expression was decreased in colorectal cancer by comparison with normal controls, especially in stage III disease. In contrast, actRII expression was similar in both groups whereas actRIb and actRIIb were below the level of detection. The decrease in actRI levels and the apparent absence of actRIb and actRIIb raises the possibility that cancer cells in colon carcinomas are resistant to activin mediated growth inhibition. For example, levels of the type I TGF- $\beta$ receptor are decreased in approximately $30 \%$ of pancreatic cancer and this decrease has been shown to be associated with decreased responsiveness to TGF- $\beta 1 .^{49}$ Taken together with the fact that about $20 \%$ of sporadic colorectal cancers exhibit Smad4 mutations and $7 \%$ exhibit Smad2 mutations, ${ }^{6}{ }^{50} 51$ these findings suggest that a variety of perturbations in the activin $\beta \mathrm{A}$ signalling pathway in colon cancer cells may render them resistant to activin mediated growth inhibition.

Current molecular models for colorectal cancer implicate serial genetic alterations as the basis of cancer formation. These alterations include perturbations in the APC/ $\beta$-catenin pathway, overexpression of $\mathrm{COX} 2, \mathrm{p} 53$, and DNA mismatch repair gene mutations, K-ras mutations, and microsatellite instability that is associated with mutations in the type II TGF- $\beta$ receptor. ${ }^{6}$ Approximately $90 \%$ of colorectal cancers with microsatellite instability and $15 \%$ of sporadic colorectal cancers harbour mutations in this receptor. ${ }^{6}$ Mutations in either the type II TGF- $\beta$ receptor or in the Smad4 or Smad2 gene $^{50}{ }^{51}$ render colon cancer cells resistant to the growth inhibitory actions of TGF- $\beta .{ }^{6}$ Ostensibly, the cancer cell derived TGF- $\beta$ dimers can then exert paracrine effects to promote angiogenesis, suppress cancer directed immune mechanisms, and alter the extracellular matrix in a manner that enhances cancer spread and metastasis. ${ }^{52}$ In this context, it is noteworthy that deletion of the Smad4 genes through homologous recombination in HCT116 human colorectal cancer cells that originally contained two normal Smad4 alleles results in loss of both TGF- $\beta 1$ and activin responsiveness. ${ }^{53}$ Furthermore, among all TGF- $\beta$ family members, activin most resembles TGF- $\beta$ in its mode of receptor activation and receptor structure. ${ }^{54}$ Taken together with the finding that inhibin $\beta \mathrm{A} /$ activin $\mathrm{A}$ is markedly overexpressed in stage 
IV colon cancer, these observations raise the possibility that, like TGF- $\beta$, activin A may act via paracrine mechanisms to promote colon cancer spread. In addition, our findings suggest that activin A may serve as a marker of advanced colorectal cancer.

This work was supported by Public Health Service Grant CA-75059 awarded by the National Cancer Institute to D Korc. Dr Wildi was the recipient of a postdoctoral trainee award from the Ursula Zindel-Hilti-Foundation and the Ciba-GeigyAnniversary Foundation. He is a research fellow of the Department of Visceral and Transplantation Surgery of the University Hospital of Bern, Switzerland. Dr Kleeff was the recipient of a fellowship award from the University of California Research and Education Grant on Gene Therapy for Cancer.

1 Parker SL, Tong T, Bolden S, et al. Cancer statistics, 1997. CA Cancer f Clin 1997;47:5-27.

2 Metzger U. Recent developments in molecular biology, screening, and treatment of colorectal cancer. Curr Opin Oncol 1990;2:738-46.

3 Burt RW. Colon cancer screening. Gastroenterology 2000; 119:837-53.

4 Tominaga T, Sakabe T, Koyama Y, et al. Prognostic factors for patients with colon or rectal carcinoma treated with resection only. Five-year follow-up report. Cancer 1996;78: 403-8.

5 Pietra N, Sarli L, Sansebastiano G, et al. Prognostic value of ploidy, cell proliferation kinetics, and conventional clinicopathologic criteria in patients with colorectal carcinoma: a prospective study. Dis Colon Rectum 1996;39:494-503.

6 Chung DC. The genetic basis of colorectal cancer: insights into critical pathways of tumorigenesis. Gastroenterology 2000;119:854-65.

7 Massagué J. TGF- $\beta$ signal transduction. Annu Rev Biochem $1998 ; 67: 753-91$.

8 Heldin CH, Miyazono K, ten Dijke P. TGF- $\beta$ signaling from cell membrane to nucleus through Smad proteins. Nature 1997;390:465-71.

9 Avery A, Paraskeva C, Hall P, et al. TGF- $\beta$ expression in the human colon: differential immunostaining of the crypt epithelium. Br f Cancer 1993;68:193-201.

10 Friedman E, Gold LI, Klimstra D, et al. High levels of transforming growth factor $\beta 1$ correlate with disease progression in human colon cancer. Cancer Epidemiol Biomarkers Prev 1995;4:549-54.

11 Tsushima H, Kawata S, Tamura S, et al. High levels of transforming growth factor beta 1 in patients with colorectal cancer: association with disease progression. Gastroen terology 1996;110:375-82.

12 Markowitz S, Wang J, Myeroff L, et al. Inactivation of the type II TGF-beta receptor in colon cancer cells with microsatellite instability. Science 1995;268:1336-8.

$13 \mathrm{Lahm} \mathrm{H}$, Odartchenko N. Role of transforming growth factor beta in colorectal cancer. Growth Factors 1993;9:1-9.

$14 \mathrm{Lu}$ SL, Kawabata M, Imamura T, et al. HNPCC associated with germline mutation in the TGF-beta type II recepto gene. Nat Genet 1998;19:17-18.

15 Zhu Y, Richardson JA, Parada LF, et al. Smad 3 mutant mice develop metastatic colorectal cancer. Cell 1998;94: 703-14.

16 Findlay J. An update on the roles of inhibin, activin, and follistatin as local regulators of folliculogenesis. Biol Reprod listatin as local

17 Meunier H, Rivier C, Evans RM, et al. Gonadal and extragonadal expression of inhibin $\alpha, \beta \mathrm{A}$, and $\beta \mathrm{B}$ subunits in various tissues predicts diverse functions. Proc Natl Acad Sci USA 1988;85:247-51.

18 Attisano L, Wrana JL, Montalvo E, et al. Activation of signaling by the activin receptor complex. Mol Cell Bio 1996;16:1066-73.

19 TenDijke P, Ichijo H, Franzen P, et al. Activin receptor-like kinases: a novel subclass of cell-surface receptors with predicted serine/threonine kinase activity. Oncogene 1993;8 2879-87.

20 Mathews LS, Vale WW. Expression cloning of an activin receptor, a predicted transmembrane serine kinase. Cell 1991;65:973-82.

21 Attisano L, Wrana JL, Cheifetz S, et al. Novel activin receptors: distinct genes and alternative splicing generate a repertoire of serine/threonine kinase receptors. Cell 1992;
68:97-108.

22 Alley MC, Scudiero DA, Monks A, et al. Feasibility of drug screening with panels of human tumor cell lines using a
microculture tetrazolium assay. Cancer Res 1988;48:589microc

23 Raitano AB, Korc M. Tumor necrosis factor up-regulates gamma-interferon binding in a human carcinoma cell line. f Biol Chem 1990;265:10466-72.

24 Chomczynski P, Sacchi N. Single-step method of RNA iso-phenol-chloroform extraction. Anal Biochem 1987;162:156-9.

25 Korc M, Chandrasekar B, YamanakaY, et al. Overexpression of the epidermal growth factor in human pancreatic cance is associated with concomitant increase in the levels of epidermal growth factor and transforming growth factor alpha. I Clin Invest 1992;90:1352-60.

26 Friess H, Yamanaka Y, Büchler M, et al. Enhanced expression of transforming growth factor beta isoforms in human pancreatic cancer correlates with decreased survival. Gastroenterology 1993:105:1846-56.

27 Siebert PD, Larrick JW. PCR MIMICS: Competitive DNA fragments for use as internal standard in quantitative PCR. Biotechniques 1993;14:244-8

28 Kleeff $\mathrm{J}$, Ishiwata $\mathrm{T}$, Friess $\mathrm{H}$, et al. Concomitant over-expression of activin/inhibin beta subunits and their receptors in human pancreatic cancer. Int $\mathcal{f}$ Cancer 1998;77:860-8.

29 Ishiwata T, Kornmann M, Beger HG, et al. Enhanced fibroblast growth factor 5 expression in stromal and exocrine elements of the pancreas in chronic pancreatitis. Gut 1998; 43:134-9.

30 Kleeff J, Ishiwata T, Maruyama H, et al. The TGF-beta signaling inhibitor Smad7 enhances tumorigenicity in pancreatic cancer. Oncogene 1999;18:5363-72.

31 Kleeff J, Maruyama H, Ishiwata T, et al. Bone morphogenetic protein 2 exerts diverse effects on cell growth in vitro and is expressed in human pancreatic cancer in vivo. Gastroenterology 1999;116:1202-16

32 Vale W, Rivier J, Vaughan J, et al. Purification and characterization of an FSH releasing protein from porcine ovarian follicular fluid. Nature 1986;321:776-9.

33 Ling N, Ying SY, Ueno N, et al. Pituitary FSH is released by a heterodimer of the beta-subunits from the two forms of inhibin. Nature 1986;321:779-82.

34 Zhang Z, Zhao Y, Batres Y, et al. Regulation of growth and prostatic marker expression by activin $\mathrm{A}$ in a androgensensitive prostate cancer cell line LNCAP. Biochem Biophys Res Comm 1997;234:362-5.

35 Dalkin AC, Gilrain JT, Bradshaw D, et al. Activin inhibition of prostate cancer cell growth: selective actions on androgen-responsive LNCaP cells. Endocrinology 1996; 137:5230-5.

36 McCarthy SA, Bicknell R. Inhibition of vascular endothelial cell growth by activin A. F Biol Chem 1993;268:23066-71. 37 Liu QY, Niranjan B, Gomes P, et al. Inhibitory effects of activin on the growth and morphogenesis of primary transformed mammary epithelial cells. Cancer Res 1996;56: $1155-63$

38 Yasuda $\mathrm{H}$, Mine $\mathrm{T}$, Shibata $\mathrm{H}$, et al. Activin-A: an autocrine inhibitor of initiation of DNA synthesis in rat hepatocytes. 7 Clin Invest 1993;92:1491-6.

39 Kojima I, Ogata E. Dual effect of activin A on cell growth in Balb/c 3T3 cells. Biochem Biophys Res Comm 1989;159: 1107-13.

40 Rabinovici J, Spencer SJ, Jaffe SR. Recombinant human activin-A promotes proliferation of human luteinized preovulatory granulosa cells in vitro. F Clin Endocrinol Metab 1990;71:1396-8.

$41 \mathrm{Yu} \mathrm{J}$, Shao L, Vaughan J, et al. Characterization of the potentiation effect of activin on human erythroid colony formation in vitro. Blood 1989;72:952-60.

42 Di Simone N, Crowley WF Jr, Wang QF, et al. Characterization of activin/inhibin subunit, follistatin, and activin type II receptors in human ovarian cancer cell lines: a potential role in autocrine growth regulation. Endocrinology 1996; 137:486-94.

43 Matzuk MM, Finegold MJ, Jyan-Gwo JS, et al. $\alpha$-inhibin is a tumor suppressor gene with gonadal specificity in mice. Nature 1992;360:313-19.

44 Coerver KA, Woodruff TK, Finegold MJ, et al. Activin signaling through activin receptor type II causes the cachexialike symptoms in inhibin-deficient mice. Mol Endocrinol 1996;10:534-43.

45 Thomas TZ, Wang H, Niclasen $\mathrm{P}$, et al. Expression and localization of activin subunits and follistatins in tissues from men with high grade prostate cancer. 7 Clin Endocrinol Metab 1997;82:3851-8.

46 Zheng W, Luo MP, Welt C, et al. Imbalanced expression of inhibin and activin subunits in primary epithelial ovarian cancer. Gynecol Oncol 1998;69:23-31.

47 Petraglia F, Florio P, Luisi S, et al. Expression and secretion of inhibin and activin in normal and neoplastic uterine tissues. High levels of serum activin A in women with endometrial and cervical carcinoma. 7 Clin Endocrinol Metab 1998;83:1194-200.

48 Kalkhoven E, Roelen BA, de Winter JP, et al. Resistance to transforming growth factor beta and activin due to reduced receptor expression in human breast tumor cell lines. Cell Growth Differ 1995;6:1151-61.

49 Wagner M, Kleeff J, Lopez ME, et al. Transfection of the type I TGF-beta receptor restores TGF-beta responsiveness in pancreatic cancer. Int $\mathcal{f}$ Cancer 1998;78:255-60.

50 Riggins G, Kinzler K, Vogelstein B, et al. Frequency of Smad gene mutations in human cancers. Cancer Res 1997; 57:2578-80.

51 Eppert K, Scherer SW, Ozcelik H, et al. MADR2 maps to $18 \mathrm{q} 21$ and encodes a TGF $\beta$-regulated MAD-related protein that is functionally mutated in colorectal cancer. Cell 1996;86:543-52.

52 Gold LI. The role for transforming growth factor-beta (TGF-beta) in human cancer. Crit Rev Oncog 1999;10: 303-60.

53 Zhou S, Buckhaults P, Zawel L, et al. Targeted deletion of Smad 4 shows it is required for transforming growth factor $\beta$ and activin signaling in colorectal cancer cells. Proc Natl Acad Sci USA 1998;95:2412-16.

54 Kingsley DM. The TGF-beta superfamily: new members, new receptors, and new genetic tests of function in different organisms. Genes Dev 1994;8:133-46. 